\title{
REGIONAL CHALLENGES AND EXPORT PERFORMANCE OF PAKISTAN (2004 - 2017)
}

\author{
* Farhana Kauser, Research Scholar, Department of International Relations, Federal \\ Urdu University, Karachi (farhanakauser13@gmail.com) \\ ** Shahnawaz Mohammad Khan, Lecturer, Department of International Relations, \\ Federal Urdu University, Karachi (han_smart17@hotmail.com)
}

\begin{abstract}
Pakistan is a less advanced South Asian nation, which is appraised as an underdeveloped nation, its economy is generally in view of horticulture. Pakistan's exports have been on the declining side for as far back as 10 years, particularly in the article of clothing industry, because of its neighbours India and Bangladesh have influenced Pakistan's exports of textile and leather. Then again, exhibition of warfare industry in the form of "IDEAS" has been held after every 2 years throughout the previous 10 years, is helping Pakistan's economy to move from farming to arms and ammo generation. Despite, Pakistan has not done advancement as far as changing over the economy from cultivation to most recent innovation yet at the same time its doing sensibly well in working together with quick advancing nations, for example, China. Therefore, we can state that there's yet far to go to take the exports on a level where proportion of exports is higher than one of imports. Progressive developments should be taken like the quick developing nations whose exports are considerably higher than imports.
\end{abstract}

KEYWORDS: Pakistan, Export, Rice, Cotton, Business, Policy.

\section{INTRODUCTION}

Pakistan is the 66th greatest export economy in the world and the 110th utmost multifaceted economy according to the Economic Complexity Index (ECI). In 2015, Pakistan exported USD 26.2 B and imported USD $45.5 \mathrm{~B}$, realizing a negative trade modify of USD $19.3 \mathrm{~B}$. In 2005, the GDP of Pakistan was USD 271 B and the GDP for each capita was USD 5.01K. The best Pakistani exports are house-hold (USD $2.99 \mathrm{~B}$ ), rice (USD 1.91 B), cotton yarn (USD 1.75 B), non-weave men suit (USD $1.49 \mathrm{~B}$ ) and overpowering woven cotton (USD 1.01 B), using the 1992 adjustment of the HS (Harmonized System) arrange. Its best imports are refined oil (USD 5.46 B), unpleasant oil (USD 2.74 B), palm oil (USD 
$1.58 \mathrm{~B}$ ), scarp press (USD $945 \mathrm{~m}$ ) and automobiles (USD $807 \mathrm{~m}$ ). The best export objectives of Pakistan are the USA (USD 3.93 B), China (USD $2.44 \mathrm{~B}$ ), Afghanistan (USD 1.95 B), Germany (USD $1.62 \mathrm{~B}$ ) and the United Kingdom (USD $1.48 \mathrm{~B}$ ). The best import beginnings are China (USD 11.9 B), the United Arab Emirates (USD 5.38 B), Saudi Arabia (USD $3.01 \mathrm{~B}$ ), the USA (USD $1.96 \mathrm{~B}$ ) and Indonesia (USD $1.92 \mathrm{~B}$ ). Pakistan edges China, India, Iran and Afghanistan by means of land and Oman by means of sea. (Masakure, Henson \& Cranfield, 2009).

\section{DETERIORATING ERA IN PAKISTAN'S EXPORTS}

Overall exports of Pakistan have deteriorated by more than $12 \%$ in the vicinity of 2013 and 2015. This decline is perplexing, especially as lesser oil charges since 2014 were required to cure the business deficiency. The normal standpoint, as announced by the State Bank of Pakistan, for 2016 does not look encouraging. Add up to exports were accounted for at USD 18 B between January 2016 and October 2016. This figure is lower than the aggregate exports of USD $19 \mathrm{~B}$ revealed for the relating time frame in 2015. (Rana, 2017) In spite of the fact that, the decrease in exports is ascribed to a worldwide log jam sought after, the pattern must be researched as the export base for Pakistan isn't just restricted to a couple of items yet is for the most part limited to low-esteemed items that are vulnerable to value stocks.

Acquiring information from UN COMTRADE and item arrangements from World Integration Trade Solution(WITS), the declining pattern in exports is inspected beneath. The exports of Pakistan are basically bound for the US, the Middle East and the EU, at around 24\%, $15 \%$ and $11 \%$ separately in 2013. As of late in the wake of arranging a free trade agreement with China in 2007, the exports have gushed. The EU granted the GSP plus status to Pakistan in 2014, which was given for enhancing the exports from Pakistan. (Narula, 2016)

Like the worldwide pattern, the offer of exports from Pakistan to the United States and the EU has expanded near 2013 and 2015. Pakistan exported over $30 \%$ of its aggregate exports to the EU in 2015 and $17 \%$ to the US. In any case, in supreme numbers, exports from Pakistan to the US have fallen. Then again, the estimation of exports from Pakistan to EU has expanded near 2013 and 2015, which is probably going to be driven by the special treatment to Pakistan's exports imported under the GSP plus scheme. Pakistan exports chiefly textile and leather items, which 
aggregately constituted around 78\% of the aggregate exports in 2015. Their offer in all out exports from Pakistan expanded near 2013 and 2015. The portion of textile items in worldwide trade is somewhat under $5 \%$. (Rana, 2017)

\section{STATISTICS OF PAKISTAN'S EXPORT OVER THE LAST DECADE}

- Throughout the previous five years, it has a normal development of 6-7\%.

- Pakistan had a limited base, yet because of the government's steps, it has expanded over the most recent five years.

- Pakistan acquires a noteworthy segment of remote trade from the exports of its items, for example, pieces of clothing, logical, medicinal and healing facility gear, toys, bikes, wear products and so on.

- Non-military personnel flying machine, PC frill, media transmission gear, tanks, mounted guns, rockets, firearms, ammo and so forth are among the significant exports.

- Over the last five years, inflation has hiked. Currently, the rate of inflation is $25 \%$.

\section{INDUSTRIAL SEGMENTS}

1. Agriculture

2. Automobile

3. Cement

4. IT

5. Textile

6. Electronics

7. Aviation

8. Livestock

9. Machinery

10. Pharmaceutical

11. Defence

12. Food

13. Sports

14. Miscellaneous

Classification of Pakistan's exports: 
Garments, cotton apparels and household furniture account for over $80 \%$ of Pakistan's exports, worth USD 2.6B (70.6\% of exports of Pakistan to United States are hiked by $18.6 \%$ from 2005$)$.

- Garments, cloth and fabric worth USD 351M (9.6\% down to $5.6 \%)$.

- Household furnishing and other textile products worth USD138.3M (3.8\% up by $11.6 \%)$.

- Floor wares i.e. mats, carpets worth USD $122.1 \mathrm{M}$ (3.3\% declined to $2.1 \%$ ).

- Non-textile products and furnishing worth USD $81.4 \mathrm{~m}$ (2.2\% up by $7.2 \%$ ).

- Sporting good, camping equipment, gears and footwear worth USD $61.2 \mathrm{~m}(1.7 \%$ up by $4.7 \%)$.

- Hospital, medical, and other scientific equipment worth USD 37.9 m (1\% up by $10.4 \%)$.

- Other sporting goods, toys and bicycle worth USD $34.4 \mathrm{~m}(0.9 \%$ up by $16.5 \%)$.

- Synthetic fabric and clothing worth USD $23.7 \mathrm{~m}$ (0.6\% up by $39.1 \%)$.

- Kitchen cutlery, housing and gardening gears worth USD $21.4 \mathrm{~m}$ $(0.6 \%$ up by $10.2 \%)$.

\section{RAPIDLY GROWING EXPORT OF PAKISTAN}

- Organic industrial chemicals worth USD 13.6 m (up by $339 \%$ from 2005).

- Confectionary and bakery items worth USD 5.3 m (up by 197\%).

- Assorted products i.e. non-edible oils, waxes, tobacco etc worth USD $18.8 \mathrm{~m}$ (up by $119 \%$ ).

- Parts and accessories for automotive industry worth USD $2.8 \mathrm{~m}$ (up by $115 \%$ ).

- Fruits and other products i.e. juices worth USD $4.4 \mathrm{~m}$ (up by 104\%). 


\section{REPLANCMENT OF PAKISTAN'S EXPORT}

- Pakistan's exports do not have any sort of replacement.

- Only the mentioned products are available for Pakistan to export.

- Replacements are likely to be declined by the importers.

- Pakistan exports agricultural products and these commodities do not have available replacements.

\section{PERFORMANCE OF EXPORT (2004-05):}

With an aim of USD 13.7 B, exports reached an amount of USD $14.42 \mathrm{~B}$ by the end of last year.

\section{EXPORT GARMENTS AND TEXTILE}

Garments and textile clothing attributed $25.2 \%$, its urging to take consideration of that five of the subsectors in particular cotton fabric, knitwear, bed product, readymade articles of clothing and cotton yarn accomplished exports in overabundance of USD 1 B each amid year 200405 .

\section{RICE EXPORT}

During 2004-05, rice exports, at USD $933 \mathrm{~m}$, hiked over the consistent period of the previous year.

\section{MECHANICAL AND ENGINEERING GOODS}

Exports of engineering and mechanical goods through this period enlarged by USD $101 \mathrm{~m}$, bookkeeping for a 5\% increase. (Weiss, 2005),

\section{PERFORMANCE OF EXPORT (2005-06)}

\section{COMPLICATIONS:}

In the first place, on 8th October 2005, the fast increment in the worldwide oil costs.

\section{THE FACILITATING SECTOR}

Pakistan's economy for a ton of reasons including business, commitment to GDP and as a driver of monetary development. 


\section{EXPORT OF MERCHANDISES}

- Previous year, the aimed export target was USD $17 \mathrm{~B}$.

- Our standard exports were around USD 16.5 B. As far as divisions, amid the time of July 2005 to May 2006.

- Textile exports increased by USD 1.39 B.

- Rice exports hiked by USD $178 \mathrm{~m}$.

- Exports of leather products increased by USD $152.5 \mathrm{~m}$.

- Exports of petroleum products improved by USD $242 \mathrm{~m}$.

- Chemical exports enlarged by USD $23.1 \mathrm{~m}$.

- While different various things likewise enhanced by USD $888 \mathrm{~m}$.

\section{PERFORMANCE OF EXPORT (2006-2007)}

Amid the initial 11 months of 2006-07, for instance, the oil imports expanded by $11.1 \%$ when contrasted with a similar time of $2005-06$. Notwithstanding the difficulties that our exports have needed to look amid the most recent year, they have still kept on developing.

\section{TEXTILE EXPORT}

Throughout the initial 11 months of $2006 \& 2007$, the textile exports expanded by $6 \%$. Among these, art silk and manufactured materials have developed by $122 \%$, tents and canvas by $99 \%$ and cotton yarn by $82.7 \%$. (Bader, 2006)

Amid the initial 11 months of 2006-07, development rate of textile exports expanded to $60 \%$ from 14\%, amid the relating time of 2005-06. Inside the material gathering, the export of bed product declined by $3.1 \%$, cotton fabric by $4.1 \%$ and export of crude cotton diminished by $21.7 \%$. (Din, Ghani, , \& Mahmood, 2009).

\section{DIFFERENT ELEMENTS INFLUENCING PAKISTAN'S EXPORT DEVELOPMENT}

Tough common rivalry in textile items from China, India, Vietnam and Bangladesh in our real markets of the U.S. what's more, the EU, NAFTA and CAFTA. The setting up of U.S. supported qualified mechanical zones in Jordan and Egypt fall in unit costs in the textile part. 
The 5.8\% normal hostile to dumping obligations in the European market on our bed-material exports.

\section{CAUSES OF TRADE DEBIT IN PAKISTAN}

- Power shortage

- Political uncertainty

- Lack of business opportunities

- Increased oil exports

- Country crop trafficking

- Little return on investment

- Work force

\section{PORTION OF USER GOODS IN EXPORTS}

Shopper merchandise are essentially completed items, for example, textile items, while middle of the road products are raw materials, for example, cotton yarn and raw cotton separately, require additionally handling before being sold as buyer merchandise. The offer of purchaser merchandise to add up to exports to the EU from Pakistan expanded from $70 \%$ of every 2013 to $77 \%$ out of 2015. (Ministry of Commerce, 2015)

A comparable pattern was watched for the overall exports from Pakistan in the textile business. The aggregate exports of buyer items in the textile business expanded by around USD $565 \mathrm{~m}$ yet the exports of intermediate products and raw materials diminished by roughly USD 160 m.

Besides, the export of customer items in the textile business to the EU expanded by USD $747 \mathrm{~m}$. This recommend the exports of significant worth included consumer items, especially in the textile business, to the EU performed generally very much contrasted with the raw materials and intermediate merchandise amid the most recent couple of years as exporters of the buyer items were more compelling in engrossing the request stun. The exports to the United States from Pakistan diminished over all previously mentioned item arrangements. Roughly $67 \%$ of all shopper products exported by Pakistan were bound for the European Union and the United States. This number increment to over $86 \%$ of the purchaser products exported in the textile business. (Masakure, Henson, \& Cranfield, 2009). 


\section{NON- TARIFF MEASURES}

Importing nations may layout solid necessities to control the nature of their imports. Non-tariff measures (NTMs), for example, sterile and phytosanitary measures on plants and creatures and additionally specialized obstructions to trade basically on non-farming products, forced by importing nations to confine substandard imports into their nation.

Under NTMs, exporters might be required sure rules on size, shape and capacity of a specific item. Many assignments have a tendency to get dismissed by importing nations if the item does not meet to the prerequisites. This expands the settled expenses to trade for exporters trade to bigger exporters, who can manage the cost of the expenses related with the NTMs. (Takalvi, 2017)

The propelled nations, such EU and the United States, have a tendency to force larger amount of non-tariff measures, from developing nations, especially where substandard items are made. Along these lines, trade arrangements ought to guarantee that trade deterrents due to nontariff measures are decreased with the goal that new exporters can partake in global trading exercises.

\section{PERFORMACE OF PAKISTANI'S EXPORTS}

Pakistan has done genuinely well financially since its independence more 60 years prior and is the 27th biggest economy on the planet with a for every capita wage of more than 3500 dollars in buying power equality. Nonetheless, export execution has been dull and far beneath its potential, constituting a piece of $0.15 \%$ of overall global exports. It turns out to be additionally discouraging of contrasted and different nations which began their advancement procedure in the meantime as Pakistan and with nearly a similar starting condition amid the most recent two decades, China's exports have expanded more than sixoverlay, India's exports have developed more than five times. Likewise, Turkey, Vietnam and Bangladesh have additionally done fine in their endeavours to advance their business. (Atique \& Ahmad, 2003)

In correlation, Pakistan's exports have expanded just 2.7 times over the period, mirroring it's not as much as fulfilled execution, setting it among the low doers on this score. There are many purposes for this low 
standard execution for example, precariousness in political framework, totalitarianism in the nation for very nearly 40 years and absence of long haul political arrangements.

OUTLINE OF PAKISTAN'S EXPORT

\begin{tabular}{|l|l|}
\hline Exporting Years & Exporting Volume \\
\hline $2005-06$ & USD 15.43 B \\
\hline $2006-07$ & USD 16.91 B \\
\hline $2007-08$ & USD 19.07 B \\
\hline $2008-09$ & USD 17.68 B \\
\hline $2009-10$ & USD 19.20 B \\
\hline $2010-11$ & USD 25.34 B \\
\hline $2011-12$ & USD 24.61 B \\
\hline $2012-13$ & USD 20.14 B \\
\hline $2013-14$ & USD 20.99 B \\
\hline $2014-15$ & USD 24.55 B \\
\hline
\end{tabular}

Source: SBP Annual Report on the State of the Economy 2015-2015

\begin{tabular}{|l|l|l|l|l|}
\hline $\begin{array}{l}\text { Food } \\
\text { Group } \\
\text { Exports }\end{array}$ & $\begin{array}{l}\text { Textile } \\
\text { Group } \\
\text { Exports }\end{array}$ & $\begin{array}{l}\text { Petroleum } \\
\text { Group } \\
\text { Exports }\end{array}$ & $\begin{array}{l}\text { Other } \\
\text { Manufacturing } \\
\text { Exports }\end{array}$ & $\begin{array}{l}\text { Engineering } \\
\text { Group } \\
\text { Exports }\end{array}$ \\
\hline $\begin{array}{l}2010-11 \\
\text { USD 3.3 B }\end{array}$ & $\begin{array}{l}2010-11 \\
\text { USD 10.02 } \\
\text { B }\end{array}$ & $\begin{array}{l}2010-11 \\
\text { USD 1.1 B }\end{array}$ & $\begin{array}{l}2010-11 \\
\text { USD 3.8 B }\end{array}$ & $\begin{array}{l}2010-11 \\
\text { USD 0.2 B }\end{array}$ \\
\hline $\begin{array}{l}2012-13 \\
\text { USD 4.5 B }\end{array}$ & $\begin{array}{l}\text { USD 13.08 } \\
\text { B }\end{array}$ & USD 1.4 B & $\begin{array}{l}2012-13 \\
\text { USD 4.5 B }\end{array}$ & $\begin{array}{l}2012-13 \\
\text { USD 0.3 B }\end{array}$ \\
\hline 2013-14 & 2013-14 & 2013-14 & 2013-14 & $2013-14$ \\
USD 4.7 B & USD 14 B & USD 1.5 B & USD 4.9 B & USD 0.3 B \\
\hline
\end{tabular}

Source: SBP Annual Report on the State of the Economy 2015-2015 


\section{SHARE OF COUNTRIES IN EXPORT:}

$17 \%$ to United States of America, 9\% to United Arab Emirates, $8 \%$ to Afghanistan, $7 \%$ to China, 5\% to United Kingdom, 5\% to Germany, 3\% to Turkey, $3 \%$ to Italy, $3 \%$ to Bangladesh, $2 \%$ to Belgium and $35 \%$ to other countries. (Ministry of Commerce, 2015)

\section{S.W.O.T STUDY}

Pakistan has a solid similar favourable position in agricultural products because of its soil enrichment, water system and human power. Considerable fixation on conventional resource base and low approval items chiefly delivered for native captive showcase at offering at high costs, rinsing the feeling to export by enhancing quality depending on work escalated innovation with restricted generation base of brilliant produces because of absence of $R \& D$ ethos and services in industrial segments of Pakistan. Expanding expenses of manufacturing are making our items costly in global market. Deferred transferences because of energy shortages and lawfulness security circumstance. Exports of couple of things to constrained goals are bringing about ferocious rivalry among our exporters in bring down costs nonappearance of clear long haul plans concerning export development during recent decades. (Ahmed, Mahmud, Hamid, \& Rahim, 2010).

Expanding global population and developing worldwide affluence is fuelling the interest for new items. Globalization with chaperon extension of market, effortlessness of communication and quick conveyance of products and services with expanding outsourcing openings from advanced nations because of expanding expense of manufacturing. There is more prominent likelihood of securing an upper hand by importing raw material, not accessible locally.

\section{GSP + AWARD}

Status on 1st January 2014 is relied upon to give a further lift to the nation's developing prospects through expanded trade and remote speculation with the European Union. Shift of enterprises from advanced nations to advancing nations in the wake of worldwide remaking joint venture concurrence with businessmen of the nations having raw material 
however need ability and assets. Developing thriving of Pakistani diaspora is quick to purchase merchandise and ventures of Pakistan.

Pakistan's picture as an exporter of low quality, low cost of chose merchandise and ventures, limiting the interest for top notch items from Pakistan. Lawfulness security circumstance preventing the importers to visit Pakistan or partake in trade displays. Energy shortage makes somewhat more issues among them importers about the sureness of auspicious conveyance of products. (Gul, \& Rehman, 2014),

Rise of solid rivals in the area in a similar export group where Pakistan has a near edge are expanding worries of the importing nations about social and ecological issues, the green innovation, child labour, sexual orientation equality, limited work and so on. Moving of Pakistan's businesses to different nations because of push-pull factor. Pakistan's significant export partners, the United States of America, the European Union, China and the Middle East are confronting a financial log jam. the previously mentioned factors are influencing Pakistan's exports.

\section{STEPS TO ENHANCE EXPORT OF PAKISTAN}

Expanding the volume and scope of exporting amazing products and enterprises despite expanding rivalry in a quickly globalizing world. Definition of business well-disposed national financial arrangements which support production of exportable overflow of top notch merchandise and enterprises with motivations for innovative work and esteem expansion. These approaches ought to fortify each other and any hostile to export predisposition found in any strategy ought to be expelled.

Plan of a complete trade strategy which ought to demonstrate the wide heading for this division, make organizations and characterize their divisions, shape rules for coordination, to set security and quality gauges and give a motivating force and reward framework for different partners. Inside this system, governments administer ought to be bound to enactment, approach, limit building and help, while the private division should lead the pack in investment and production chain advancement all alone. Expansive goals of this strategy could include:

Raise efficiency by expanding effectiveness in every one of those segments headed towards exports productivity of all partners by giving the proper inducements and reward. Making exports aggressive in the quickly globalizing world. Guaranteeing manageability by advancing condition 
inviting great and assembling works on, guaranteeing transmission of increases from improved profitability to all partners. (Masakure, Henson, \& Cranfield, 2009).

\section{FAST - TRACKING THE DEVELOPMENT RATE OF PAKISTAN}

By enhancing its remote trade income through expanded export of products and ventures. Destitution easing and diminishment in wage differences through production of openings for work in sports division. Pulling in foreign ventures by lessening expenses of working together, giving suitable encouraging force and making business friendly conditions. Modernization of every single financial division by presenting new innovations and systems. (Akbar, \& Naqvi, 2001).

The best advancement methodology fortifies a nation's export quality and makes the premise of setting up new upper hand. Our methodology in this way ought to be to build the quantum of our exports as well as to expand their range, getting high esteem included useful for export into the current and new markets. When we have chosen the coveted segments of our export list and the business sectors in which we centre our consideration, it is anything but difficult to focus and the usage. We should guarantee that all aggressiveness of exports is accomplished and kept up. For this reason, we should address the financial and trade related issues that are assuming significant part in influencing the general aggressiveness of a nation's endeavours in the worldwide export market.

Expanding exportable surplus limit use, limit extension profitability development, quality control, confronting difficulties of WTO Regime, empowering open private association, lessening exchange costs, drawing in foreign capital, defending import approach, keeping up discerning swapping scale, reviving fiscal discretion, social and ecological consistence urging SMEs to export. (Mahmood, 1981)

On account of the past measures, there is a considerable portion of limit in each industrial unit which can't be used for one reason or other exorbitant imported raw material, absence of fund, insufficient BMR, deficiency of expertise and so on. There is a requirement for completing a thorough investigation of all the export arranged units and discover answer for ideal use of their overabundance limit. Industries which have lost their significance or aggressive edge we should make strong strides and let them kick the bucket. (Haque, 2009) 


\section{NECESITY FOR ENHANCING THE CAPACITY}

Identified with above is the requirement for expanding the limit both of existing units or building new ones. Without different discover the generation base we can't enhance our export profile. We should choose the products and enterprises to be advanced for exports on the premise of their relative preference, international demand and development potential-the sun rise ventures. Some of this sun rise businesses are electronic and media transmission gear, car parts, natural pharmaceuticals, sustainable energy, petrochemicals, aviation and so on.

A financial measure of yield per unit of info (the proportion of GDP to add up to hours worked in the economy amid a measuring period), profitability picks up are key to the economy since they enable us to finish more with less. Put resources into physical capital and advancing advancement i.e. fruitful misuse of new thoughts, aptitudes arrangement expected to exploit interest in new advances and authoritative structure by expanding work efficiency through instruction, on work preparing, ability of graduation and scattering of new information and strategies. Rivalry when endeavours contend with existing firms, it guarantees that assets are apportioned to the most proficient firms and powers existing firms to arrange work all the more productively. (Mahmood, \& Akhtar, 1996)

There's a necessity to advance the way of quality at each phase value chain and even among the customers through mindfulness movement, suitable enactment, institutional instrument and so on. There ought to be strict quality control measures for local size of products and enterprises to ensure our makers value cognizant, obligatory value declaration alongside endowment to the producer of super quality items, opening of facilitation outlets to diminish the cost of making and guaranteeing quality of items. Globalization is a double-edged weapon, it gives prospects yet in addition postures challenges. Just those nations will have the capacity to benefit from this wonder which acknowledge the difficulties and think of fitting reactions

\section{PAKISTANI EXPORT AND INTERNATIONAL FINANCIAL INSTITUTE}

Pakistan has gained critical ground in recapturing macroeconomic steadiness in the course of recent years. Pakistan has accomplished 


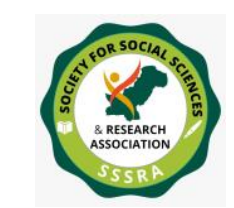

Regional Challenges and ,...

macroeconomic steadiness in the previous three years: the financial shortfall has contracted from 8 percent to beneath 5 percent, universal stores have tripled to over $\$ 18 \mathrm{~b}$, and the rate of development has expanded by a full rate point to 4.7 percent.

Financial pointers in the main portion of FY17 propose that weights are mounting for both monetary union and outside parities. The present record deficiency will dramatically increase in FY19 from 1.1 percent of GDP in FY16. Stores are figure to be around $\$ 18$ by FY19, still well over three months of imports. The financial shortage will augment from 4.5 percent of GDP in FY16 to 5.1 percent in FY18, and will decrease marginally to 4.9 percent in FY19. Pakistan has likewise set out on an eager auxiliary changes program. Usage record has been blended. There were early accomplishments in tax assessment, the money related part, the business condition (at both the national and common levels), and the power segment. Notwithstanding, noteworthy changes attempted in the power division have slowed down since the Government halted privatization a year back. (Ministry of Commerce, 2015)

Roundabout obligation cleared before has heaped up again about to its 2013 levels. There have been endeavours to diminish the power controller's freedom. Advance in enhancing improvement results have been blended and venture levels stay low, at around 15 percent of GDP (both open and private). Keeping up macroeconomic steadiness and further advance in auxiliary changes will be important to quicken development and guarantee it is comprehensive and maintainable.

Development, however unstable and low in a few periods, has been very ace poor in Pakistan over the previous decade and a half. The headcount destitution rate has fallen reliably finished this period, from 34.7 percent in FY01/02 to 9.3 percent in FY13/14 (utilizing the most recent review information and the old neediness line). Utilizing occurrence bends that plot the development rate in utilization at every percentile of the conveyance, it is obvious that development has been ace poor in Pakistan through quite a bit of this period. Taking a gander at the last 40 percent of the populace - a measure of shared thriving-we see a comparable example. The Government received an overhauled technique to quantify destitution and another neediness line in 2016. Under the modified destitution line, the neediness head tally has declined from 64.3 percent in FY01/02 to 29.5 percent in FY13/14. Our comprehension of what has caused this huge decrease in neediness stays deficient. Imperative patrons 
are higher GDP development in the prior years, solid development in settlements, viable social help programs and fast and 'shrouded' urbanization which has prompted an exceptionally dynamic casual area. (Gul, \& Rehman, 2014)

Many years of inside political debate and low levels of remote venture have prompted moderate development and underdevelopment in Pakistan. Pakistan has an expansive English-talking populace. By and by, a testing security condition, power deficiencies, and an oppressive venture atmosphere have prevented financial specialists. Agribusiness represents one-fifth of yield and two-fifths of business. Materials and attire represent the vast majority of Pakistan's fare profit; Pakistan's inability to expand its fares has left the nation powerless against shifts in world request. Pakistan's GDP development has slowly expanded since 2012. Official joblessness was $6 \%$ of every 2017 , except this neglect to catch the genuine picture, since a great part of the economy is casual and underemployment stays high. Human advancement keeps on falling behind the greater part of the area. (Pasha, 2017)

In 2013, Pakistan set out on a \$6.3 B IMF Extended Fund Facility, which concentrated on decreasing vitality deficiencies, settling open accounts, expanding income gathering, and enhancing its adjust of instalments position. The program closed in September 2016. In spite of the fact that Pakistan missed a few auxiliary change criteria, it reestablished macroeconomic strength, enhanced its FICO score, and helped development. The Pakistani rupee, after overwhelming deterioration in 2013, remained generally stable against the US dollar in 2015-17. (Takalvi, 2017) Low worldwide oil costs in 2016 added to a narrowing current record shortfall and lower expansion. Settlements from abroad laborers kept on being a key income source, likewise relieving the effect of the absence of remote venture and a developing exchange shortage on the nation's present record. (Pasha, 2017)

Pakistan must keep on addressing a few longstanding issues, incorporating growing interest in instruction and medicinal services, adjusting to the impacts of environmental change and cataclysmic events, enhancing the nation's business condition, decreasing reliance on outside givers, and broadening the nation's expense base. Given statistic challenges, Pakistan's initiative will be squeezed to actualize monetary changes, advance further improvement of the vitality area, and pull in outside venture to help adequate financial development important to utilize 
its developing and quickly urbanizing populace, a lot of which is younger than 25. (Bader, 2006)

\section{CONCLUSION}

It is basic to seek after industrial and trade arrangements that advance esteem expansion inside Pakistan. Such a methodology ought to include an attention on the export of shopper merchandise to their more important goal markets. This will guarantee a lessening in unpredictability of exports. Regardless of gigantic steps made by Pakistan in the field of financial improvement amid over six many years of its independence, its export profile isn't as great as it ought to have been. Pakistan's dependence on excessively couple of exportable things and excessively few exchanging partners have made the nation powerless against exterior and also interior stuns. Pakistan should extend its manufacturing list, differentiate it considering need premise and specialty a forceful long-haul export system, it additionally needs to justify its monetary strategies in a state of harmony with the new technique attempting solid endeavours to improve our exports by broadening them. 


\section{REFERENCES}

Ahmed, H., Mahmud, M., Hamid, N., \& Rahim, T. (2010). A strategy for reversing Pakistan's dismal export performance (Policy Paper No. 01-10). Lahore, Pakistan: Centre for Research in Economics and Business.

Akbar, M., \& Naqvi, Z. F. (2001). External market conditions, competitiveness, diversification, and Pakistan's export performance. Pakistan Development Review, 40(4), 871-884.

Atique and Ahmad, (2003), The supply and demand for export of Pakistan: The polynomial distributed lag model approach, The Pakistan Development Review, 42: 961-972.

Bader, S. (2006). Determining Import Intensity of Exports for Pakistan. SBP Research Bulletin, vol. 2(2), pp. 363-381.

Din, M., Ghani, E., \& Mahmood, T. (2009). Determinants of export performance of Pakistan: Evidence from firm-level data. Pakistan Development Review, 48(3), 237-240.

Gul, S. and Rehman, S.U. (2014), Determinants of Pakistan's export performance, Pakistan Business Review, 15:544-562

Haque, I. (2009). The rise of bilateralism in trade and its implications for Pakistan [Special edition]. Lahore Journal of Economics, 14, 111-133.

Mahmood, A., and Akhtar, N. (1996), "The Export Growth of Pakistan: A Decomposition Analysis", The Pakistan Development Review, 35: 693702 .

Mahmood, Z. (1981), "Changes in Export Shares and Competitive Strength in Pakistan", The Pakistan Development Review, 20: 399-415.

Masakure, O., Henson, S., \& Cranfield, J. (2009). Standards and export performance in developing countries: Evidence from Pakistan. Journal of International Trade and Economic Development, 18(3), 395-419. 
Ministry of Commerce, (2015) September 30, "Study on Reasons of Decline in Exports," National Tariff Commission.

https://ntc.gov.pk/wp-content/uploads/2016/05/Study-on-Reasons-ofDecline-in-Exports.pdf

Narula, T.T.,(2016) "How to boost Pakistan's dwindling exports," Pakistan Today.

https://www.pakistantoday.com.pk/2016/11/06/how-to-boost-pakistansdwindling-exports/

Pasha, H.,(2017) "What has caused Pakistan's alarming trade deficit?" Dawn, July 24, https://herald.dawn.com/news/1153812

Rana, S., (2017) "Pakistan's exports to most regions have plunged," The Express Tribune,. https://tribune.com.pk/story/1463589/pakistans-exportsregions-plunged/

Takalvi, I (2017) “Dark Clouds Over Pakistan's External Trade,” Daily Pakistan,

https://en.dailypakistan.com.pk/opinion/dark-clouds-over-pakistansexternal-trade-what-is-actually-wrongwith-our-exports/

Weiss, J. (2005), "Export Growth and Industrial Policy: Lessons from the East Asian Miracle experience", Discussion Paper, 26. Tokyo: ADBI. 